\title{
メンテナンスサービスと行動計測* \\ Behavior Measurement in Maintenance Service
}

\section{蔵田武志 ${ }^{* *}$ 興梠正克 ${ }^{* *}$ 石川智也 ${ }^{* *}$ Anjin Park ${ }^{* *}$ \\ Takeshi KURATA, Masakatsu KOUROGI, Tomoya ISHIKAWA and Anjin PARK}

\section{1. は じめに}

持続発展可能な社会の実現が急務になってきたことに歩 調を合わせて，メンテナンス，リユース，リサイクル等の 環境サービスの存在感が日増しに強くなっている。メンテ ナンスサービスに限っても，例えば，日本標準産業分類に おいて,「ビルメンテナンス業」は 1994 年に細分類として 設定され，2008 年には，「プラントメンテナンス業」が 「その他の技術サービス業」に内容例示された. 市場規模 的に見ても, ビルメンテナンス業は 2007 年時点で約 3.5 兆円（社団法人全国ビルメンテナンス協会調查）に達して おり，引き続き堅調な伸びを続けている。一方，プラント メンテナンス業の市場規模は 2006 年時点で約 8500 億円 (日本メンテナンス工業会調査) であったが, 電力会社, メーカーなどが自社業務としている部分等は含まれないた め, 実際にはこちらも数兆円規模の産業である.

メンテナンスサービスに含まれる業務としては，例え ば，点検，整備，修理，清掃等がその代表的なものとして あげられる，機器・装置の稼動状況遠隔点検（ネットワー クでのモニタリング）を除けば，それらの多くは，従業員 の作業によって提供されているといっても過言ではない が，それ故に経験と勘で補われているオペレーションも 多い.

従業員の作業や業務内容は，作業報告書，業務日報，申 し送り表等に記録されるが，一般的には従業員による記入 作業が伴う。作業履歴が蓄積されれば業務分析・サービス プロセス再設計等を工学的に取り組むことができ, 情報共

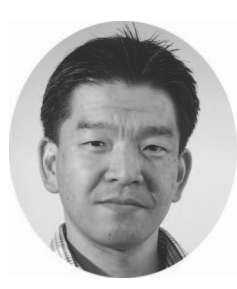

*原稿受付 2010 年 1 月 13 日

㜔産業技術総合研究所サービス工学研究センター （茨城県つくば市梅園 1-1-1 中央第 2) 蔵田武志

1996 年筑波大学大学院工学研究課修士課程修 了. 現在, 産業技術総合研究所サービス工学研 究センターサービス工学企画室長. 2003〜2005 年 JSPS 海外特別研究員（ワシントン大客員研 究員) を兼務. 2009 年から筑波大学大学院准教 授 (連携大学院) を兼務. IEEE, 日本 VR 学会, 電子情報通信学会, 情報 処理学会各会員. 博士 (工学).
有も進むが，作業記録を厳密にしようとすればするほど， その記入作業自体が従業員に高い負荷を与えてしまうこと になる。 また，プラントメンテナンスやビルメンテナンス では移動と作業の繰り返しが頻繁に起きるため, その場で 即座に記録を取りづらい状況や，他の従業員がどこで何を しているかを把握しづらい状況もしばしば発生する。

これらは, 多くの労働集約型産業における共通の課題と もいえるが，比較的業務プロセスや製造プロセスの最適設 計をしやすい動脈産業との大きな違いの 1 つが，このよう な人間系の比率の高さとそれ故のサービス現場の状況の把 握しづらさである. 加えて, 従業員のスキルのばらつきの 大きさも最適なサービスプロセスの設計や適用を一層困難 にしている.

\section{2. サービス生産性と行動計測}

従来からメンテナンスサービス等の労働集約型産業では いわゆる人時生産性を指標として用いることが多いが，筆 者は図 1 に示すサービス生産性という考え方を取り入れ る必要が出てくると考えている，それは，サービスプロセ スを高効率化していくことはもちろんであるが，さらに， 社会要請 (GRC 支援やエコ化等) に応え, 従業員満足度 や人材育成効果を向上させ，サービスプロセスを再設計し やすくすることも考慮したメンテナンスサービスの実現が

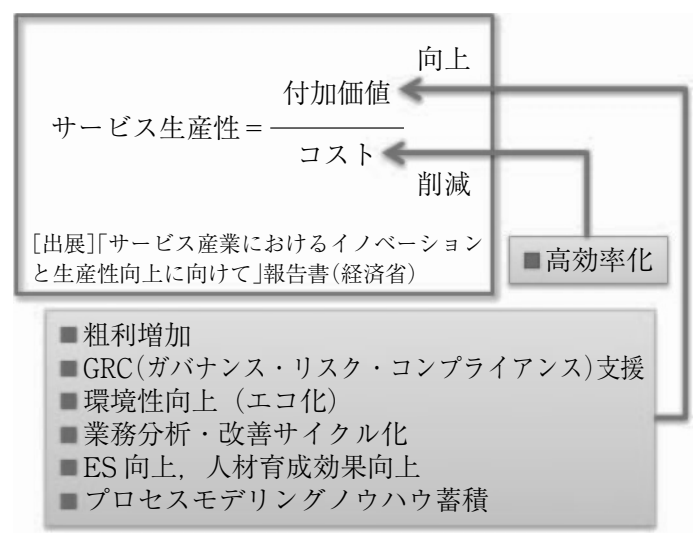

図 1 サービス生産性 
求められていくことになるからである。なお，このサービ 又生産性の絶対值の定量化は容易ではないが，少なくと も, サービスプロセス変更指針を検討する際や, 変更前後 の相対比較をする際の指標等として適用可能である。メン テナンスサービスの効率化やエコ化と前章で述べた諸問題 軽減を含めてサービス生産性を向上させることを考えた場 合，従業員の行動やサービス現場の状況の見える化はその ための有効な第 1 歩であるといっても過言ではないであ ろう。

\section{3． 行動計測と複合現実情報循環}

作業者の行動を常時計測できるようにして見える化し， サービス現場を実験室として活用できれば，サービス工学 的アプローチで柔軟なサービス設計と適応的なサービス適 用が実現できると考えられる。一方で，サービス現場への 介入には特に人的コストや通常のオペレーションを妨げる リスクが伴う場合があるが，サービス現場を仮想化した環 境を構築できれば，現場検証に用いる仮説（設計）の枝杊 りなどの効率化が可能になる。

複合現実 (MR) 技術は, 実世界（人・物事・環境）の 情報化 ·仮想化, 実世界と仮想物体などの情報との幾何学 的 ·光学的 - 時間的 - 意味的な整合性を必要に応じて考慮 した情報提示, さらにそれらのサイクルをさまざまな粒度 で総合的に扱う技術分野である。 そのため, MR 技術はサ ービス現場の実験室化と仮想化のためのコア技術の 1 つで あるといえるが，その普及には，図 2 に示すようなセン サ情報やその履歴，インタフェース操作履歴，コンテンツ

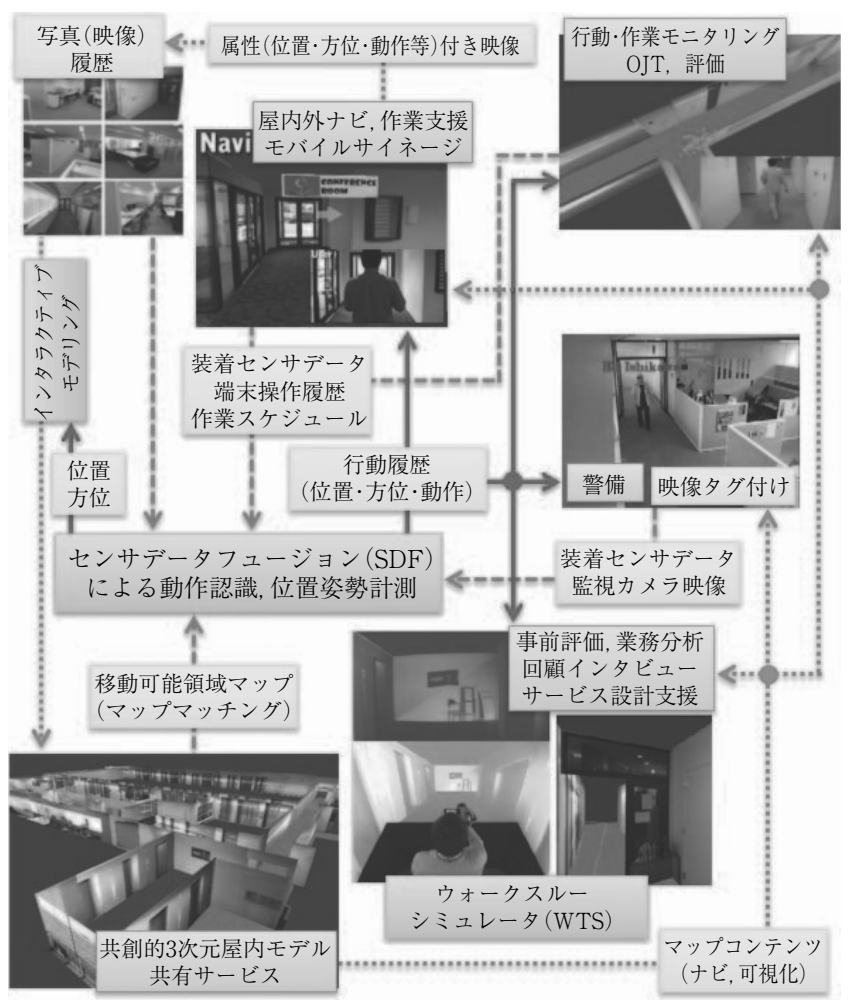

図 2 複合現実技術に基づく情報循環
等の情報循環の枠組みを構築して, 各技術の導入コストを 分散させ，社会実装性，持続発展可能性を高める必要があ $ろ^{1)}$.

サービス現場の実験室化に有効な技術の 1 つとして人間 行動計測のための歩行者デッドレコニング（PDR） ${ }^{233)}$ に基 づくセンサデータフュージョン (SDF) 技術がある. PDR は, 装着型自蔵センサ群（加速度, 角速度, 磁気, 気圧など）のセンサ情報に基づく歩行者用の自律式推測航 法である，センサの装着位置によって手法が分かれる ${ }^{4) 5}$ が, 腰部装着の場合, 加速度・角速度の時系列パターンで 歩行動作の認識と歩行速度の推定を行う. また, 重力方 向，角速度，地磁気情報をカルマンフィル夕等で組み合わ せることで, ジャイロのドリフト, 磁場の歪みや外乱要因 などの各センサの欠点を補償しながら姿勢（向き）を推定 する，位置は，それらを用いた積算処理により逐次更新さ れる，単なる測位と異なり，向きの情報も得られるため, コンテキスト認識に非常に有効な技術であるといえる.

ただし，PDRの性能がいくら向上しても累積誤差を取 り除くことは困難であり，また，絶対位置を与える必要が あるため, 通常は SDF 技術を適用することになる ${ }^{6}$. こ れにより，PDRの補正ができるだけでなく，過度にイン フラに依存することがなくなるため, 例えば, LPS (Local Positioning System) で必要とされる装置の設置密 度を低く抑えることができるようになる，また，画像べー スの手法の場合は，登録デー夕数を削減することができ

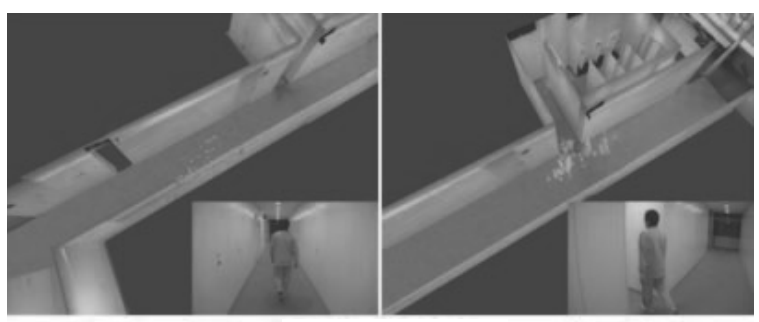

通路を移動

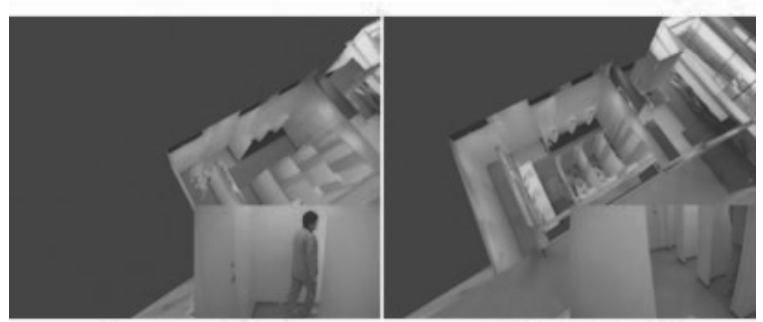

トイレに到着

個室を清掃

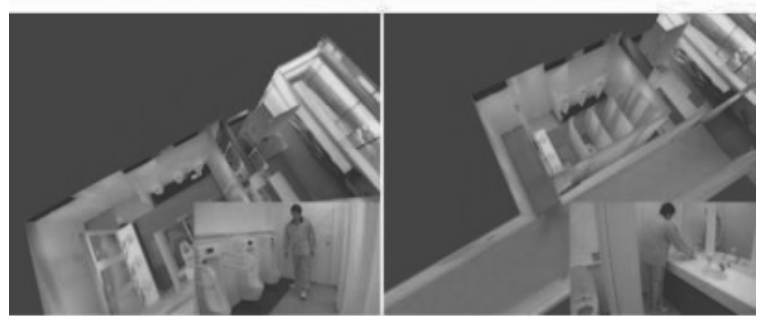

洗面台を清掃

図 3 清掃作業の計測と可視化 


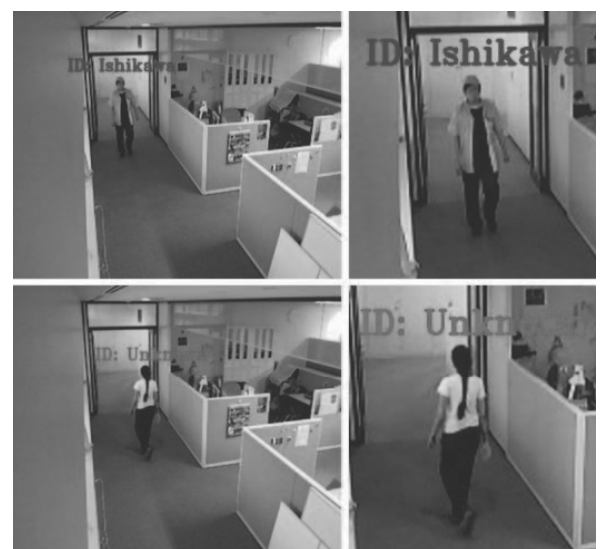

図 4 PDR と監視カメラでそれぞれ得られた軌跡情報を統合した PDR 補正と監視映像への自動夕グ付け（上：PDR 装置を装着 した作業者，下：PDR 装置未装着の人が通過した例）

る．さらに，作業者の存在確率分布に基づくマップマッチ ングにより精度を向上させることもできる。マップマッチ ングに利用する情報は，3D 地図などの人間のためのコン テンッブが整備されていればそれを再利用することも可能 である

PDR で用いられるセンサは，もちろん，歩行以外の行 動認識にも適用可能であり，歩く，走る，座る，（特定の） 作業する，エレベー夕に乗るなどの動作種別と位置や向き とを同時に獲得し，詳細な行動デー夕を取得することも技 術的には可能になりつつある。その動作種別識別には, SVM や AdaBoost などの機械学習手法が広く適用されて いる ${ }^{8)}$. また機器操作履歴等と組み合わせて動作の種類を 限定することで，識別精度を向上させることもできる。

図 3 は，清掃作業を模擬した被験者の移動履歷を計測 した実験例である。この例では初期值は手動で設定し, PDR とマップマッチングを用いたパーティクルフィルタ によって位置姿勢を更新している。 また，工場やショッピ ングモールなどの施設内の巡回警備時等には, PDR と監 視カメラの SDF も有効である（図4).

\section{4. 仮想化現実環境での行動観測}

サービス利用者・提供者にとって頻繁に起こる状況の 1 つに「サービス現場内の（特に歩行による）移動と比較的 単純な作業の繰り返し」がある。これはメンテナンスサー ビスの従業員の多くにも当てはまる。このような状況を仮 想的に再現し, 行動選択理解 (CCE: Cognitive ChronoEthnography）やそれに基づく事前評価等を実現するため に，筆者らはハンズフリー全方位ウォークスルーシミュレ ータ（WTS）の開発を進めている（図 5 $)^{9}$. サービス現 場の再現に主眼を置くと主に，サービス利用者や提供者間 での情報共有に関する調查研究に適した設計とするため, WTS では，他のサービス利用者・提供者との対話による 情報共有，手持ちデバイス（ハンディターミナル）や紙 （地図，チェックリスト等）による情報共有を仮想環境で 実現する

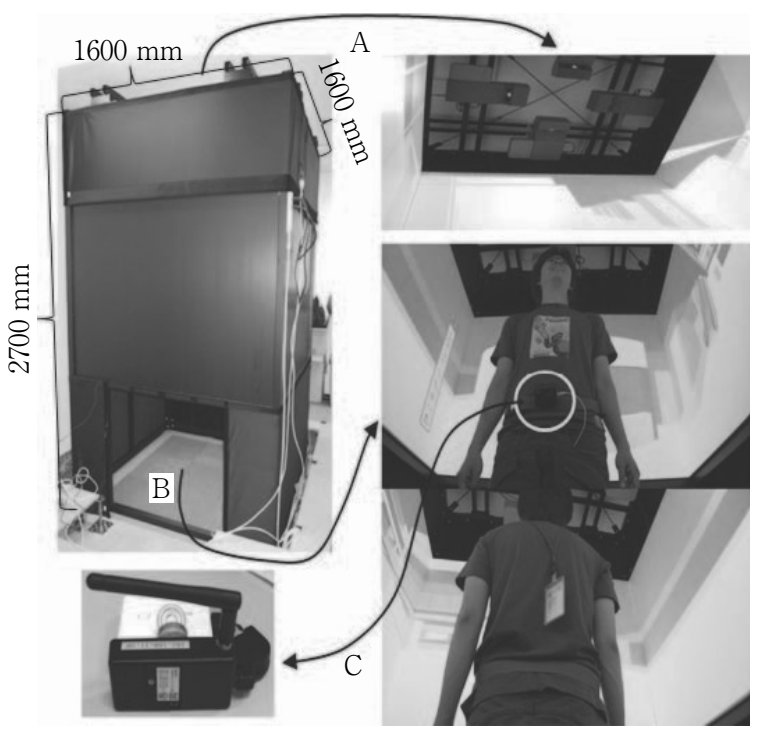

图 5 サービス現場で頻発する状況を再現可能なハンズフリー全方 位ウォークスルーシミュレータ（WTS）

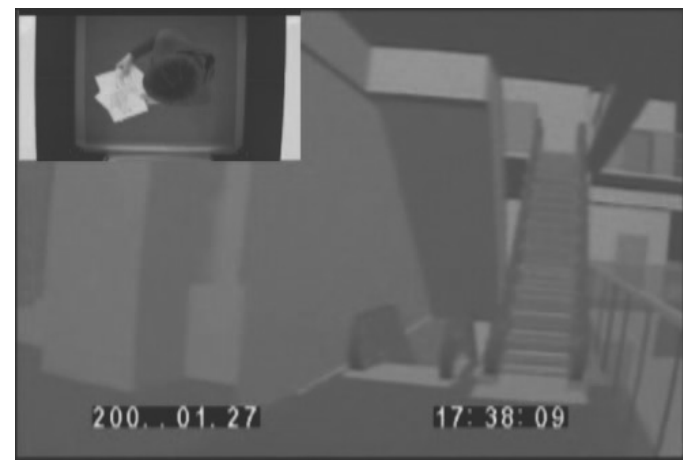

エスカレータに乗ろうとしている

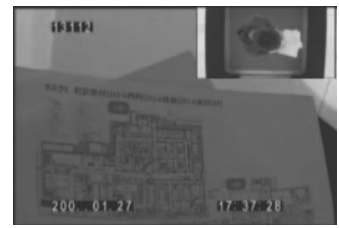

手に持った地図を確認

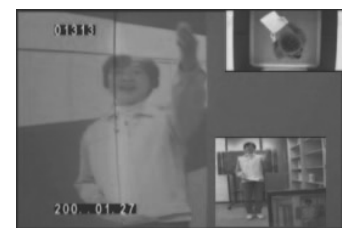

従業員のアバ夕と会話
図 6 WTS 内で地図を見たり，他の従業員と会話したりしながら， 情報を得て, 目的地に向かっている様子

仮想化されたサービス現場に扔ける被験者実験におい て，仮想環境と実環境との違いに起因するノイズ混入を抑 制しながら前述の状況を再現する必要がある。そのため, まず，PDR センサモジュールを用いた足踏み動作と体の 回転による操作体系を開発している。これにより，絶対方 位感覚を維持することができ，VR 酔いを抑制することが できる，また，ハンズフリーであるため，手持ちデバイス による情報共有と作業支援を再現できる．PDR デバイス を用いることによる実際の歩行と足踏みとの対応付けも検 討を始めている，さらに，他のサービス利用者・提供者と の対話は情報共有の調査研究のための重要な要素であるた め，画像処理技術に基づいてリアルタイムに生成される他 のサービス利用者・提供者の写実的アバ夕による遠隔対話 
機能を提供している ${ }^{10)}$.

このような事前評価環境の社会実装性を向上させるた め，コンパクトで簡易な機構を採用して複製を容易にして いる．評価実験時の最大のコストの 1 つは，被験者（特に サービス提供者）の拘束時間である。そのため, サービス 現場近くでの実験を可能とするために可搬性も重要になっ てくると考えられる.

\section{5. おわりに}

本稿では，サービス現場の実験室化と仮想化によるサー ビス設計の効率化等に資する複合現実情報循環技術につい て紹介し，メンテナンスサービスとの親和性の高さについ ても述べた。行動計測やその見える化から日報等の自動記 録までにはまだ飛躍があり，今後は，計測データからの日 報半自動生成等の技術開発が必要である。また，WTSの ような仮想化環境での事前評価によるサービス設計の有効 性の検証も今後の課題である.

\section{参 考 文 献}

1）蔵田武志, 興梠正克, 石川智也, 朴鴈振 : 複合現実技術に基づ くサービス連携と共創的情報循環，第 10 回計測自動制御学会シ ステムインテグレーション部門講演会, (SI2009).
2) M. Kourogi, N. Sakata, T. Okuma and T. Kurata : Indoor/Outdoor Pedestrian Navigation with an Embedded GPS/RFID/Selfcontained Sensor System, Proc. ICAT, (2006) 1310-1321.

3) M. Kourogi and T. Kurata: Personal Positioning Based on Walking Locomotion Analysis with Self-Contained Sensors and a Wearable Camera, Proc. ISMAR, (2003) 103-112.

4）興梠正克, 大隈隆史, 石川智也, 蔵田武志: 装着型自蔵センサ モジュールを用いた歩行者の位置・方位計測技術, 電子情報通 信学会学会誌, 92,4（2009）268-275

5）舘暲, 佐藤誠, 廣瀬通孝監修：バーチャルリアリティ学, 工業 調査会, (2010).

6) T. Ishikawa, M. Kourogi, T. Okuma and T. Kurata : Economic and Synergistic Pedestrian Tracking System for Indoor Environments, Proc. SoCPaR, (2009) 522-527.

7) T. Ishikawa, K. Thangamani, M. Kourogi, A.P. Gee, W. Mayol, K. Jung and T. Kurata: In-Situ 3D Indoor Modeler with a Camera and Self-Contained Sensors, Proc. HCII, LNCS 5622,（2009） 454464.

8) M. Kourogi, T. Ishikawa and T. Kurata, A Method of Pedestrian Dead Reckoning Using Action Recognition, Proc. PLANS 2010 (to appear).

9）朴鴈振, 大隈隆史, 興梠正克, 石川智也, 蔵田武志：ハンズフ リー全方位ウォークスルーシミュレータ, 日本 VR 学会第 29 回 複合現実研究会, (2009).

10) A. Park, K. Jung and T. Kurata: Codebook-based Background Subtraction to Generate Photorealistic Avatars in a Walkthrough Simulator, Proc. ISVC, LNCS 5875, (2009) 500-510. 